\title{
Translation of Adverbs of Manner from English to Indonesian: Content Analysis of Charlotte's Web Novel by E. B. White
}

\author{
Resty Widya Kurniasari \\ Universitas Pakuan, Bogor, Indonesia \\ Email: resty28.rwk1@gmail.com
}

\begin{abstract}
The purpose of this research is to obtain an overall view of the translation of adverbs of manner from English to Bahasa Indonesia. This study used a qualitative approach using a content analysis method. The data used in this study are all sentences which are positive, negative, and interrogative sentences, including translation strategies and translation shifts (of the meaning). The data source in this study is Charlotte's Web novel by E.B. White in English as the source text and the translation in Bahasa Indonesia (Laba-laba dan Jaring Kesayangannya) as the target text translated by Dina Begum.
\end{abstract}

Keywords: Charlotte's Web, Translation, Adverbs of Manner.

\section{A. INTRODUCTION}

The translation is an activity of switching messages from one language to another language. Nida and Taber state that translation is an attempt to recreate messages in Source Language (BSu) to Target Language (BSa) with the natural match as close as possible, first in terms of meaning, and then language style (Nida \& Taber, 1969). Nida \& Taber are more interested in translation activities that try to find a natural match that is as close as possible to the BSu message so that it can generate the same message in the BSa. The translation process not only translates word by word in each sentence but translates the meaning and content of the message contained in BSu.

The translation strategy can be interpreted as a step that the translator uses to gain a match in translation. Linguists often express and use the word strategy as 'method' or 'procedure' translation. Newmark uses the term 'procedure' while Mona Baker uses the term 'strategy'. Some experts use these different terms to provide solutions so that translators can produce grateful and correct translations.

In the translation of BSu text into BSa, there are often changes called shifts. This shifts can occur as a result of the search for a match from BSu into the BSa. Catford in Hatim and Munday, defines shifts as follows: Shifts as departures from formal correspondence in the process of going from the Source Language to the Target Language. This distinction drawn between formal correspondence and textual equivalence will be crucial and relates to Saussure's distinction between langue and parole. Thus, the shift departs from formal relations in the process of transferring from BSu to BSa. 
In relation to translation activities, translation shifts can be analyzed based on a class of adverbs. Adverbs are words that give a description to verbs, adjectives, or other adverbs (Alwi, 2003). Adverbs have different shapes, functions, and meanings. In form studies, adverbs can consist of noun phrases, adjective phrases, preposition phrases, and clauses. All of these aver words can explain several different meanings such as time, place, way, and so on. In addition, adverbs can be researched based on two aspects of their behavior, namely first in terms of syntax behavior (based on their position on the word or part of the sentence described by the adverb in question); and secondly in terms of semantic behavior (based on the meaning of the word in the sentence when explained by the statement in question) as stated by Alwi.

An adverb describes the meaning associated with how the event described by the adverb is taking place or occurring. The adverbs are used appropriately in Both English and Indonesian. BSu is not all translated into Bsa adverbs. There are also adverbs that are not translated because translators consider the meanings that want to be conveyed to the target reader.

\section{B. METHOD}

This research is a literature study on the translation of adverbs of manner. The object of the material used as research material is a literary work in the form of a novel entitled Charlotte's Web by E. B. White which has been translated into Indonesian into Laba-laba dan Jaring Kesayangannya.

The method used in this study is the analysis of the content by prioritizing the text in the novel. The phenomenon that will be reviewed is by looking at the translation of adverbs of manner from English into Indonesian. Content analysis is defined as "a research technique for making replicable and valid inferences from texts (or other meaningful matter) to the contexts of their use". Content analysis is an in-depth analysis that can use quantitative or qualitative techniques against messages using scientific methods and is not limited to the types of variables that can be measured or the context in which messages are created or presented.

The supporting instruments used in this study are data obtained from adverbs of manner in BSu as well as translations in BSa. The procedure for collecting data is to group data containing adverbs of manner in Charlotte's Web novels. Books, scientific journals, as well as other sources of reference from various writings and the internet are utilized as sources of reference related to the methods and theories of translation strategies and translation shifts.

\section{RESULT AND DISCUSSION}

In relation to translation, the novel can be analyzed based on the translation of adverbs or known as Adverbs of Manner. An adverb describes the meaning associated with how the event described by the adverbs is taking place or occurring. Adverbs of Manner includes translation strategies and translation deviations in the 
novel Charlotte's Web by E. B. White which has been translated into Indonesian into Spider and Its Beloved Web by Dina Begum.

\section{Literal Translation Strategy}

In literal translation, the translator has transformed the BSu structure into a BSa structure. However, the words and language styles in BSu are still retained in the BSa. Translators translate word for word based on their function and meaning. For example, in the word sadly translated into pilu, translators use literal translation strategies because they can be grateful to the target reader so that the translator does not have to search for meaning matches that match the word. Other examples are also found in the words carefully (dengan hati-hati), sleepily (dengan mengantuk), cautiously (dengan hati-hati), and sweetly (dengan manisnya).

\section{Reduction Translation Strategy}

The reduction translation strategy is carried out by the translator by reducing a word, phrase, or sentence from BSu to BSa, but the reduction has no significant meaning in the text so as not to cause the omission of important information or messages that the author wishes to convey to the reader. The word slowly in BSu translates into perlahan-lahan in its BSa. The word slowly in the Merriam-Webster Dictionary means in a slow way or low speed but the translation perlahan-lahan does not matter because although the translator does not include the word slowly, the translator does not diminish the intent or content of the message contained. The same is the case with some other examples that omit words with each adverb of manner translation.

\section{Paraphrasing Translation Strategy}

The paraphrasing strategy is carried out by the translator by creating another sentence from the sentence in BSu into the BSa without changing the meaning of the sentence. That is, the form of the sentence is paraphrased but the meaning remains the same. For example, in the Merriam-Webster Dictionary, the word dreamily means in a pleasing way (in a state of pleasure or relief). The word dreamily comes from the adjective dreamy meaning (1) imagining pleasant things and not paying attention; (2) pleasant, peaceful, and relaxing. Therefore, translators use the translation strategies or procedures put forward by Newmark that are paraphrasing (the procedure used if in the BSa is not found to match the exact term or idiom) so that the proper translation of the word dreamily is sambil melamun because it has corresponded to the context of the sentence. In addition, the translation above shows that the meaning of the word dreamily which is then translated into sambil melamun can be said to have been worth it because the translator did not attempt to change the meaning from BSu to BSa so that formal similarity was successfully achieved by the translator. The adverbs of manner translation are paraphrased by the translator so that the target reader does not experience confusion with the intent contained there in it. 


\section{Expansion of Translation Strategy}

The expansion translation strategy is carried out by adding a word to the BSa to clarify the meaning of BSu. Translators use this strategy so that the target reader does not experience confusion in interpreting the context of the sentence, so it will be easier when the translator decides to add a word to avoid that. There can be examples of expansion translation strategies in bitterly translated words with dengan nada pahit (adding the word "nada"), easily translated into dengan santai (looking for another meaning match without changing the meaning of $\mathrm{BSu}$ ), as well as triumphantly words that translate to dengan penuh kemenangan (adding the word "full"). The reason translators add the word is to strengthen the intent that wants to be conveyed from BSu to BSa.

\section{Transposition Translation Strategy}

Transposition translation strategies are carried out by translators by changing grammatical structures or exchanging positions from BSu to BSa. In this case, researchers found only one data related to transposition translation, which is in the word quickly translated into dengan cepat. When viewed from its meaning, there is clearly a formal match because the translator does not attempt to change the meaning from BSu to BSa. It's just that when translated into his BSa, the word changes position to be at the beginning of the sentence.

\section{Kuplet Translation Strategy}

The kuplet translation strategy is performed when the translator combines two different strategies for translating a text. In the three data above, translators combine transposition and reduction translation strategies. As in the word quickly and slowly that changes position when translated into cepat and perlahan. In addition, the adverbs also experienced a reduction in the word but did not change the meaning that BSu wanted to convey.

\section{Translation Shifts of Adverbs of Manner}

Translation shifts will appear in each translation. Translation shifts can cause readers to still feel that $\mathrm{BSu}$ is better than $\mathrm{BSa}$ because the translation looks like a rigid translation. It is not always possible to transfer the meaning contained in $\mathrm{BSu}$ into the BSa precisely and intact. The novel shows translation shifts. In the Oxford Dictionary, the word perfectly has meaning in a manner or way that could not be better (at all, perfectly, really). However, the translation of frozen can be said to be disproportionate (distorted) because the translator has changed the meaning of BSu. In the oline/online version of KBBI, the word freeze (membeku) means to be frozen (menjadi beku). The word frozen itself means (1) solid or hard; (2) static or rigid; (3) no longer applies, but has not been revoked; (4) difficult to understand, not intelligent; (5) may not be taken back; and (6) not resolved. Therefore, the translation of membeku has no correlation with perfectly in English. Translators should use tegap or mematung to translate words perfectly because the word tegap or mematung is more 
commensurate with the word perfectly in terms of meaning. The same case as other data such as particularly is not translated into thoughtfully and nicely.

\section{CONCLUSION}

Adverbs of Manner in Charlotte's Web novels is an interesting choice for researchers because the translation of adverbs can be examined by looking at the translation strategies used and translation shifts. It can be concluded that the translation strategy used in Charlotte's Web novels and its translations is a strategy of free translation. This is because translators are more oriented towards how the message the author wants to convey to the target reader can be accurate, grateful, and clear. Then, there are 6 strategies used to translate adverbs of manner in the novel. The adverbs of manner found in this study were as much as 5 data or $4.5 \%$. There are several reasons these data are said to be irregularities, among others: there is an addition of information in the BSa, which was not previously listed in BSu; there is an omission of information from BSu to BSa; and there is a translation of the word from BSu to BSa which is not appropriate because translators tend to retain the taste.

\section{REFERENCES}

1. A'ini, F. N. (2015). Translation Analysis On Adverb Of Manner In The Hunger Games Into The Hunger Games Novel By Hetih Rusli (Doctoral dissertation, Universitas Muhammadiyah Surakarta).

2. Alwi, H., Dardjowidjojo, S., Lapoliwa, H., \& Moeliono, A. M. (2003). Tata Bahasa Baku Bahasa Indonesia. Jakarta: Balai Pustaka.

3. Baker, M. (2000). The Translation Studies Reader. London and New York: Routledge.

4. Baleghizadeh, S., \& Dargahi, Z. (2010). The effect of nursery rhymes on EFL children's reading ability. New England Reading Association Journal, 46(1), 71-75.

5. Bell, R. T. (1991). Translation and Translating: Theory and Practice. New York: Longman.

6. Catford, J. C. (1965). A Linguistic Theory of Translation. London: Oxford University Press.

7. Efendi, N. (2014). Indonesian Translation of Adverbs in Twilight Saga Novel: New Moon.

8. Garnida, N. D. S. C. (2014). A Study of the Translation of English Adverbs of Manner into Indonesian Found in David Nicholls'one Day. PARAFRASE: Jurnal Kajian Kebahasaan \& Kesastraan, 14(01).

9. Grammar. Adverbs of Manner. Edufind online. http://www.edufind.com/englishgrammar/adverbs-manner/.

10. Hatim, B., \& Munday, J. (2004). Translation: An Advanced Resource Book. New York: Routledge.

11. Hatim, B., \& Mason, I. (1997). The Translator as Communicator. New York: Routledge. 
12. Hoed, B. H. (2006). Penerjemahan dan Kebudayaan. Jakarta: Dunia Pustaka Jaya.

13. Juliarta, I. M. (2020). Adverb of manner and its translations found in the novel "The Good Earth". International journal of linguistics, literature and culture, 6(3), 917.

14. Kridalaksana, H. (2007). Kelas Kata Dalam Bahasa Indonesia. Jakarta: Gramedia Pustaka Utama.

15. Multatuliana, L. (2007). Analysis on the translation of ad verb of manner into Indonesia (Doctoral dissertation, Thesis). Available from: http://http://www.gunadarma.ac.id).

16. Pendit, N. P. M. D. (2019). Translation Procedures in the Translation of English Adverbs of Manner (-LY) Into Indonesian. Jurnal Santiaji Pendidikan (JSP), 9(1), 813.

17. Simatupang, M. D. S. (2000). Pengantar Teori Terjemahan. Jakarta: Direktorat Jenderal Pendidikan Tinggi Departemen Pendidikan Nasional.

18. Sudirman, A. (2016). Current Issues in English-Indonesian Translation Equivalences. International journal of science and research, 5(2), 1694.

19. Tilusubya, B., Nababan, M., \& Santosa, R. (2018). Translation analysis of circumstances in the Gospel of Matthew Chapter 12 through 14 from English into Indonesian. Lingua Cultura, 12(4), 415-421.

20. Yuwono, R. I. (2017). The Analysis of Derivational Affixes Found in EB White's Novel Charlotte's Web and Its Application in Teaching Vocabulary at the Tenth Grade of Senior High School (Doctoral dissertation, PBI-FKIP). 